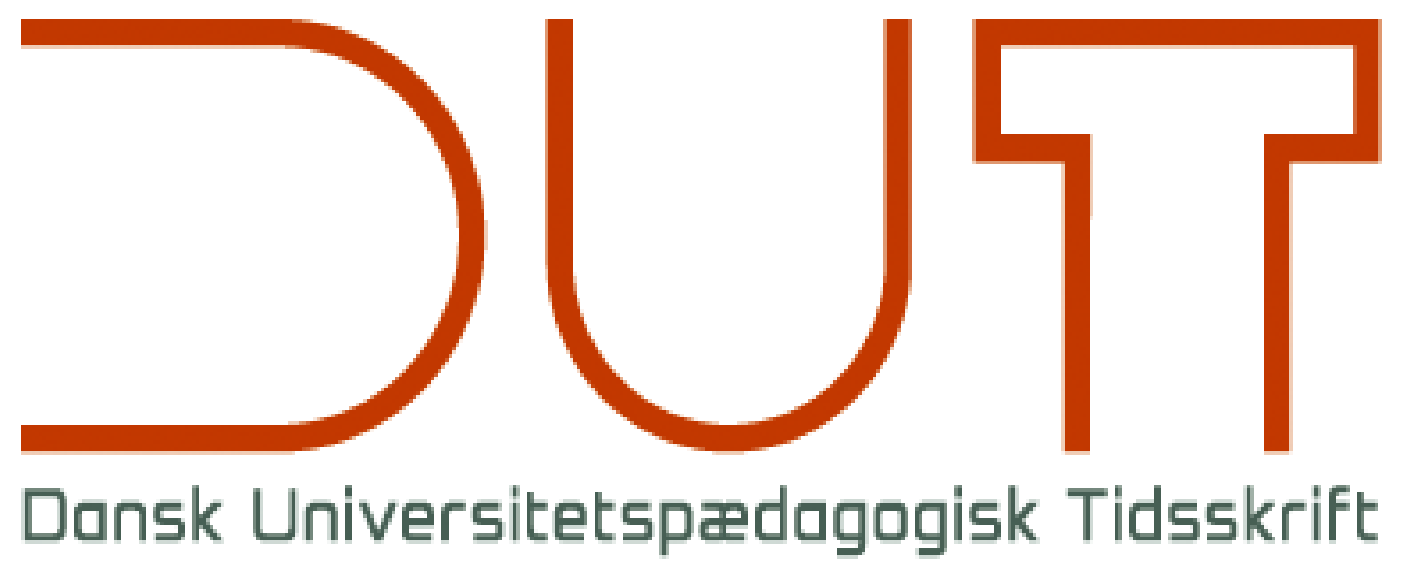

Tema

Ledelse, udvikling og overlevelse på universitetet

Årgang 12 nr. 22 / 2017

Titel

Hvordan bedømmes undervisningskompetencer ved ansættelse af videnskabeligt personale ved universitetet?

Forfatter

Sidetal

Udgivet af

URL

Sofie Kobayashi, Nana Quistgaard, Camilla Østerberg Rump og Frederik Voetmann Christiansen

$115-128$

Dansk Universitetspædagogisk Netværk, DUN

> http://dun-net.dk/

Betingelser for brug af denne artikel

(c) Copyright
Denne artikel er omfattet af ophavsretsloven, og der må citeres fra den. Følgende betingelser skal dog være opfyldt:

- Citatet skal være i overensstemmelse med "god skik“

- Der må kun citeres „i det omfang, som betinges af formålet"

- Ophavsmanden til teksten skal krediteres, og kilden skal angives ift. ovenstående bibliografiske oplysninger.

DUT og artiklens forfatter 


\section{Hvordan bedømmes undervisningskompeten- cerved ansættelse af videnskabeligt personale ved universitetet?}

Sofie Kobayashi, adjunkt ved Institut for Naturfagenes Didaktik ved Det Natur- og Biovidenskabelige Fakultet, Københavns Universitet.

Nana Quistgaard, indtil 30/6 2016 konsulent ved Institut for Naturfagenes Didaktik ved Det Natur-og Biovidenskabelige Fakultet, Københavns Universitet, p.t. freelance.

Camilla Østerberg Rump, lektor ved Institut for Naturfagenes Didaktik ved Det Naturog Biovidenskabelige Fakultet, Københavns Universitet.

Frederik Voetmann Christiansen, lektor ved Institut for Farmaci ved det Sundhedsvidenskabelige Fakultet, Københavns Universitet

\section{Reviewet artikel}

I de senere år har det ved danske universiteter været et krav, at ansøgere til videnskabelige stillinger skal vedlægge en undervisningsportfolio. Der er imidlertid ikke lavet systematiske undersogelser af, hvordan vurdering af undervisningskompetencer indgår i bedømmelsesarbejdet. Dette kvalitative studie har til formål at afdække praksis for vurdering af undervisningskompetencer på Københavns Universitet og undersøger, hvordan ansøgernes undervisningsportfolio indgår i bedømmelsesarbejdet, og hvilke kriterier bedømmere lægger til grund. Studiet bygger på interviews med ni formænd for bedømmelsesudvalg ved forskellige fakulteter. Begreberne om 'teaching and learning regimes' og 'boundary objects' danner teoretisk baggrund for studiet. Resultaterne peger på, at vurderingen af undervisningskvalifikationer er normbaseret snarere end kriteriebaseret, men at der ikke er stor forskel på normerne mellem forskellige fagområder. Respondenterne oplever, at der er en udvikling i gang i retning af mere fokus på undervisning fra både ledelsen, ansøgerne og bedømmerne. I nogle tilfælde oplever bedømmerne, at ledelsen fokuserer entydigt på ansøgernes forskning og deres potentiale i forhold til tiltrækning af eksterne midler.

\section{Introduktion}

Det er en udbredt forestilling, at forskningskompetence og videnskabelig produktion vejer tungere end undervisningskompetence ved ansættelse af videnskabeligt personale ved universiteterne. Blandt andet af denne grund er der i de senere år blevet stillet krav om, at ansøgere skal medsende en undervisningsportfolio til dokumentation af undervisningskompetence ved de danske universiteter. Dette er sket i Danmark i lighed med lande som Sverige, Holland, Canada og Australien (Christiansen, Damlund, \& Jacobsen, 2014). Der findes en del litteratur om undervisningsportfolioer 
generelt, som det fremgår af et review lavet af Christiansen et al. (2014), fx De Rijdt, Tiquet, Dochy \& Devolder (2006), Roxå \& Mårtensson (2009), (Ryegård, Apelgren \& Olsson, 2010), Seldin \& Miller (2009) samt Smith \& Tillema (2003). Der er imidlertid ikke lavet systematiske undersøgelser af, hvordan undervisningsportfolioer anvendes $\mathrm{i}$ bedømmelsessituationer eller, hvordan undervisningskompetencer faktisk indgår $\mathrm{i}$ bedømmelse ved ansættelser ved danske universiteter. De internationale erfaringer er ligeledes sparsomme (Tigelaar, Dolmans, Wolfhagen, \& van der Vleuten, 2005).

Ved Københavns Universitet har det siden januar 2011 været et krav, at ansøgere skal vedlægge en undervisningsportfolio i forbindelse med ansøgning om stillinger på lektor og professorniveau. Ansøgerne medsender i øvrigt materiale som specificeret $\mathrm{i}$ jobopslaget, herunder ansøgning, cv, publikationslister, udvalgte publikationer, forskningsplan mv. Dette materiale (i form af tekster) lægges til grund for bedømmelsesudvalgets arbejde. Bedømmelsesudvalget består typisk af tre personer, der er eksperter inden for fagområdet, og formanden er typisk intern. Det vil sige, at han/hun er knyttet til det fag eller uddannelsesområde, som jobopslaget vedrører. Bedømmelsesudvalget tager stilling til, om ansøger er fagligt kvalificeret til stillingen som beskrevet i jobopslaget og laver en beskrivelse af ansøgers medsendte materiale. På baggrund af denne indstilling indkalder dekanen de relevante kandidater til ansættelsessamtaler, hvorefter der træffes beslutning om, hvem der skal ansættes. Ved ansættelsessamtalen er dekanen eller en prodekan til stede som formand for ansættelsesudvalget. Dette består i øvrigt af formanden for bedømmelsesudvalget, institutleder, en studieleder og en studerende.

Når en stilling er slået op på KU's jobportal, indeholder opslaget (med få undtagelser) et link til retningslinjer for udarbejdelse af en undervisningsportfolio og de kriterier, som undervisningskvalifikationer vil blive bedømt ud fra. Kriterierne er gengivet $\mathrm{i}$ tekstboks 1.

\section{Kriterier for bedømmelse af undervisningskvalifikationer:}

a. Omfanget af, bredden i og dokumenteret kvalitet i ansøgeres undervisningserfaring og øvrige erfaring inden for det pædagogiske område. Med hensyn til bredde tænkes på fag, institution, målgruppe/niveau, undervisningsform og undervisningssprog. Med hensyn til dokumenteret kvalitet lægges i bedømmelsen vægt på dokumentation i form af fremlagte eksempler på undervisningsmateriale og undervisningsevalueringer.

b. Integrationen af pædagogisk praksis og pædagogisk forståelse, dvs. ansøgers demonstrerede kompetencer til på basis af egne pædagogiske forståelse - og med de studerendes læring i fokus - at analysere egen undervisning, træffe reflekterede beslutninger om dens videre udvikling og gennemføre ændringer af egen undervisningspraksis.

Tekstboks 1. Kriterier for bedømmelse, som de fremgår af Københavns Universitets Fælles retningslinjer for undervisningsportfolioer (KU, 2011). 
Som det ses, er det to forskellige ting, der skal lægges vægt på i bedømmelsen - groft sagt; på den ene side ansøgers undervisningserfaring (a) og på den anden side ansøgers pædagogiske praksis og forståelse (b). Det er ikke specificeret, hvordan bedømmerne skal vægte disse to aspekter i forhold til hinanden. I dette kvalitative studie søger vi at få et indblik i, hvordan medlemmer af bedømmelsesudvalg nærmere forholder sig til bedømmelsen af undervisningskvalifikationer. Gennem semistrukturerede interviews undersøger vi, hvordan respondenterne vurderer vægtningen af forskning vs. undervisning i bedømmelsesarbejdet, samt hvad respondenterne lægger vægt på i bedømmelsen af ansøgernes undervisningsportfolioer og deres oplevelse af, hvordan undervisningsportfolioen understøtter bedømmelsen.

Vores forskningsspørgsmål lyder:

- Hvordan vurderer bedømmelsesudvalget undervisningskompetencer ved besættelse af lektorater og professorater ved Københavns Universitet?

- Hvilken rolle spiller de centralt vedtagne vurderingskriterier for bedømmelsesarbejdet?

\section{Metode og teoretisk baggrund}

Det er vanskeligt at få indblik i, hvad der foregår i bedømmelsesudvalgene. Det skyldes primært hensynet til ansøgernes anonymitet, hvorfor vi hverken har haft adgang til ansøgningerne eller de indstillinger, bedømmelsesudvalgene har lavet. Vi har i stedet valgt at interviewe erfarne medlemmer af bedømmelsesudvalg ved alle fakulteter mere specifikt: formænd for bedømmelsesudvalg. Der er gennemført i alt ni interviews. Formænd for bedømmelsesudvalg er som hovedregel interne bedømmere, som må antages at indgå i og have egne erfaringer med det pågældende fags normer, regler og praksisformer knyttet til undervisning - eller fagets 'teaching and learning regime' (TLR) (Trowler \& Cooper, 2002). Et TLR betegner lokalt forankrede normer, regler og praksisformer knyttet til undervisning og udgør således et delaspekt af miljøets faglige kultur. Mere konkret er et TLR karakteriseret ved de ansattes opfattelse af egen underviseridentitet og deres grundholdning til undervisning og læring samt måden, hvorpå de forholder sig til magtstrukturer, der påvirker stedets praksis og diskurs omkring undervisning. Desuden handler det om mere subtile aspekter som underliggende fortolkninger og tildelinger af mening i relation til undervisning og stiltiende antagelser og uskrevne regler om fx undervisningsformer og -praksis - herunder undervisningens status i forhold til forskning. Visse dele af et TLR er i udvikling og åbne for forhandling, mens andre dele udgør relativt faste eller givne forudsætninger. Der er grund til at tro, at der er stor forskel på forskellige TLR'er mellem forskellige fagområder ved Københavns Universitet. Alle seks fakulteter er derfor repræsenteret i interviewene. Kønsfordelingen er tre kvinder og seks mænd. I udvælgelsen er der lagt vægt på at opnå spredning i faglige forskelle i de indgående discipliner og dermed antageligvis spredning i den prioritet, undervisning gives. Der er lavet interview med mindst 
to personer fra hver fire forskellige typer faglige grupperinger (Becher, 1994), som beskrevet nedenfor:

- Hard pure: fx fysik, økonomi, matematik, kemi, biologi, sprogfag. (HP1, HP2)

- Soft pure: fx antropologi, sociologi, geografi, litteraturvidenskab (SP1, SP2)

- Hard applied: fx medicin, veterinær, farmaceut, tandlæge, fødevarevidenskab (HA1, HA2)

- Soft applied: fx folkesundhedsvidenskab, jura, teologi (SA1, SA2, SA3)

Bogstavkoderne er den kode, vi har anvendt for respondenterne i resultatafsnittet, så man ud fra koderne kan se, hvilken type akademisk fag respondenterne kommer fra (men af hensyn til respondenternes anonymitet ikke hvilket fag).

Bedømmelsessituationen udgør et mødested for forskellige TLR'er repræsenteret ved interne bedømmere og eksterne bedømmere. De interne bedømmere er særligt interessante, fordi de er en del af og repræsenterer den ansættende institutions TLR. Som baggrund for bedømmelsen ligger som nævnt en række tekster, som bedømmelsen finder sted på baggrund af. Disse tekster kan opfattes som såkaldte 'boundary objects' (Akkerman \& Bakker, 2011; Star \& Griesemer, 1989). Et grænseobjekt (boundary object) er et objekt, der er tilpas fleksibelt til at kunne fungere som kommunikationsmiddel på tværs af 'intersecting social worlds' (i dette tilfælde TLR'er), men som samtidig har forskellige konkrete betydninger og stærke udmøntninger i de respektive TLR'er. I dette tilfælde har vi særligt fokus på de bedømmelseskriterier, som bedømmelsesudvalgene skal forholde sig til, og som, antager vi, kan betragtes som et sådant grænseobjekt mellem ledelsen, bedømmelsesudvalg og ansøgere. Som formand for et bedømmelsesudvalg tolker man KU's fælles kriterier på baggrund af det TLR, man kommer fra.

Målet med interviewene er at få indblik i, hvordan de interne bedømmeres TLR toner fortolkningen af det regulerende grænseobjekt (bedømmelseskriterierne), og hvordan forhandlingen af, hvad der karakteriserer forventninger til 'gode undervisere' udspiller sig i bedømmelsesudvalgene under indflydelse af bedømmelseskriterierne som grænseobjekt. Vi har derfor i interviewene valgt at fokusere særligt på bedømmernes fortolkning af ansøgernes undervisningsportfolio og af de centralt fastsatte retningslinjer for bedømmelsen af ansøgernes undervisningskvalifikationer (jf. tekstboks 1).

\section{Fremgangsmåde}

Interviewene blev gennemført som individuelle, semistrukturerede interviews baseret på den kvalitative metode beskrevet af Kvale \& Brinkmann (2009). Således blev interviewguiden udarbejdet ud fra dels forskningsspørgsmålene, dels den teoretiske fundering i 'teaching and learning regimes' og 'boundary objects'. Interviewpersonerne 
blev på forhånd bedt om at gennemse specifikke bedømmelsesudvalgsarbejder, som de havde været involveret i. Disse blev ikke videregivet til intervieweren og kun refereret i anonymiseret form. Interviewene blev indledt med generelle spørgsmål til undervisningen på interviewpersonens institut (TLR) og dernæst spørgsmål om bedømmelsesarbejder, med særlig fokus på vægtningen mellem undervisning og forskning. Herefter blev der stillet specifikke spørgsmål til, hvad der vægtes i bedømmelsen af undervisningskvalifikationer, hvordan kriterierne for bedømmelse anvendes (kriterierne som grænseobjekt), og hvordan den endelige bedømmelses undervisningsafsnit bliver til.

\section{Analyse}

Analysen af interviewene startede med en deduktiv analyse ved hjælp af teorierne om 'teaching and learning regimes' og 'boundary objects'. Der blev med udgangspunkt i Trowler \& Cooper (2002) og Akkerman \& Bakker (2011) udarbejdet en analyseramme af to forfattere i samarbejde. Uddrag af interviewene blev kopieret ind i analyserammen, hvorefter vi fulgte metoden beskrevet af Kvale \& Brinkmann (2009) og brugte en fænomenologisk tilgang til at beskrive essensen af hvert uddrag. Den deduktive såvel som den fænomenologiske analyse blev foretaget af to forfattere uafhængigt af hinanden, hvorefter alle fire forfattere diskuterede udkommet af analyserne og nåede til en fælles forståelse af essensen af interviewene.

\section{Resultater}

\section{Vægtning af forskning og undervisning i miljøerne}

De bedømmere, vi har interviewet, har meget forskellige oplevelser af, hvor vigtig undervisningen opfattes i deres miljø. Langt de fleste respondenter giver udtryk for, at forskningen vægtes højere end undervisningen - men mange giver udtryk for, at undervisningen personligt betyder meget for dem, og at undervisningen vægtes højt også af kolleger og ledelsen. Flere giver dog også udtryk for, at undervisningen ikke prioriteres tilstrækkeligt i miljøerne. I tekstboks 2 er gengivet udsagn, der viser spændvidden i udsagnene. 
SA2 "Man er primært forsker, og så er der forresten også lige det der med undervisningen"

SP1 "Jeg tror de fleste egentlig synes at det er fedt at undervise"

SP2 "Jamen for mig selv er [forskning og undervisning] sådan ideelt set som forbundne hjertekamre"

HA2 "Man sætter rent faktisk undervisningen ret højt, også fordi det er en del af vores indtægter... og derfor er det noget som vi ovenfra får besked om at det er vigtigt, og at vi skal højne det"

HP2 "Vi ser vores studerende som et produkt vi faktisk er stolte af"

HA1 "Jeg nyder det at undervise. Jeg er virkelig glad for det, men det bliver bare ikke værdsat, synes jeg"

HP1 "Hvis man er meget involveret i undervisningen, så regner folk måske lidt automatisk med [...] at man så ikke er lige så succesfuld som forsker... hvor, for mig i hvert fald, jeg har fået nogle af de der [X] midler og den slags ting, så jeg er stadigvæk ret aktiv og i hvert fald indtil videre, været en ligeså succesfuld forsker, så jeg er en af de få der ligger ret tungt på begge dele. Men det er også enormt tidskrævende. Der er ikke særlig mange, der gør det længere. Sådan har det jo været tidligere, at man godt kunne være habil indenfor begge dele, og det synes jeg ikke, der er så mange der er mere"

Tekstboks 2: Undervisningens status i forhold til forskning.

Flere giver udtryk for, at de unge undervisere (adjunkter, postdocs) har mere fokus på undervisning og er med til at påvirke undervisningskulturen i retningen af bedre undervisning. De har taget universitetspædagogikum, og det sætter et præg på den kultur, der ligger bagved - ikke blot gennem deres egen undervisning, men også ved at de ældre bliver inspireret af de unge:

HP2: "Vi har jo ansat rigtig mange unge adjunkter de senere år, og de bruger blandt andet de her kurser i pædagogik til at udvikle deres fortrolighed, også med de her teknologiske ting [..] Altså, jeg er jo adjunktvejleder[..] for en firefem stykker, og det er [..] en mere interessant oplevelse, end jeg troede, netop fordi man fär nogle inputs via de her unge folk, som man måske ikke lige selv fär gjort, fordi nu kører man bare samme kursus, som man kørte sidste år og forrige år [...] Og det tror jeg egentlig, har været for flere, lidt uventet. Ja, fordi man fär faktisk [...] også lidt input til sin egen undervisning."

\section{Hvad lægges til grund i bedømmelsen af undervisningskvalifikationer, og hvordan an- vendes kriterierne?}

I interviewene spurgte vi - før vi præsenterede vurderingskriterierne for interviewpersonerne - hvad de kigger efter i en ansøgning, når de skal vurdere ansøgerens under- 
visningskompetencer. Her starter alle respondenter (på nær én, HA2) med en beskrivelse af, hvad der svarer til kriterie (a) (jf. tekstboks 1), dvs. undervisningserfaring, bredde, relevans, niveauer, undervisningsmetoder, evt. sprog (om man har undervist på engelsk). Et par eksempler er gengivet her: 'Jamen, til at starte med kigger [jeg] simpelthen efter erfaring med undervisning'(HP2) og 'hvad for nogle typer af undervisning har folk haft, lige fra $B A, K A$, ph.d., vejledning i forskellige niveauer. Hvad for nogle kurser har de holdt, og har de kurser relevans for det, det handler om'(SP1).

Når interviewpersonerne dernæst får forelagt kriterierne, som de fremgår af de fælles retningslinjer for portfolioen, er der ikke nogen af dem, der eksplicit siger, at de kender dem i forvejen, og de fleste tager lidt tid til at tænke over det. For eksempel er én reaktion: 'Det fär man jo ikke vedsendt, så vidt jeg ved [..], så jeg vil sige, alle der sidder og bedømmer, vi har sikkert ikke læst det her nogen af os, kunne jeg forestille mig, eller fäet det at vide'(HP1). Tilsvarende angiver en anden respondent ikke at have set kriterierne, og vedkommende havde svært ved at se, hvordan man kunne vurdere deres ansøgere i forhold til de kriterier: '(a)'eren, det er rigtig, rigtig svært... [..] og (b), det er jo straks ekstremt vanskeligt'(HA2).

Generelt er respondenterne dog helt med på det kriterium (a), som de fleste allerede havde beskrevet som den umiddelbare baggrund for deres bedømmelse. Interviewene viser, at vurdering af undervisningskompetencer er et felt i udvikling, hvor respondenterne giver udtryk for, at man bevæger sig fra primært at fokusere på erfaring (a) til at inddrage både erfaring og pædagogiske kompetencer. Interviewene viser også, at det ikke er alle steder, man er nået lige langt med denne udvikling. Nogle centrale udsagn er gengivet i tekstboks 3.

HP2 “Vi følger (a)'eren, vi følger nok ikke (b)'eren ret meget...altså det er vi jo begyndt på indenfor de sidste fire-fem år"

SA2 "Det synes jeg egentlig dækker meget godt hvad der står under (b), som jeg forstår det [...] det er nok hvad vi lægger vægt på der [...] hvordan er det man forsøger at få de her pædagogiske principper man har lært på sit universitetspædagogikum ind i sin undervisning, ikke ... altså der har jo været en kæmpe opgradering af det her område i de år jeg har været her"

SA3 : "altså vi havde jo et ansættelsesforløb her meget for nylig, altså indenfor ja, en god måneds tid siden og hvor der blev lagt meget specifikt vægt på undervisningsdelen og der var meget specifikke $\varnothing$ nsker og krav om at folk fremsendte et undervisnings-cv [...] tidligere forløb jeg har siddet med $\mathrm{i}$ har det været lidt mere vekslende, fordi omstændighederne og tiden var en anden, men det her sidste var ligesom det klareste eksempel på, hvor at man tilstræber at de vægter relativt set lige meget"

SP1: "[reference til (a)] det er det vi har snakket om indtil nu ja. Og (b)... ansøgerens egen pædagogiske forståelse - den har jeg ikke tænkt så meget over, før du viser mig den nu... hvad betyder det egentlig?"

Tekstboks 3: Udsagn om udviklingen i vurdering af undervisningskompetencer. 
De fleste respondenter er meget bevidst om, at der er behov for at udvikle bedømmelsen af undervisningskvalifikationerne, og at man er i gang med en udvikling i retning af at kunne gøre dette:

"Du er så vant til at vægte og vurdere forskningspublikationer og nok en lille smule mere tøvende over for, hvordan vi vægter og vurderer undervisningserfaring ... Det skal altså på en eller anden måde opdyrkes og blive en naturlig del af den måde, man laver det der bedømmelsesarbejde på"(SA3).

Særligt vanskeligt er det at vurdere pædagogiske kompetencer, og bedømmerne giver udtryk for, at de mangler et sprog til at kunne gøre det:

"Vi går meget op i det, men det er bare svært at have et sprog til at skrive det. Så vi skriver relativt... jeg sad lige og kiggede på nogle af dem - det er meget lidt, det er sådan tre-fire linjer eller sådan noget. (...) Men det afspejler ikke praksissen"(SP1)

og:

"Men det er rigtig svært at finde ud af, hvordan folk[s], om man så må sige, pædagogiske forståelse er, også fordi vi jo ikke er pædagoger... Og derfor kan det være vanskeligt for os, der sidder i udvalget..."(HA2).

Der er altså umiddelbart stor variation i, hvor godt kriterierne fungerer - særligt er bedømmelsen af de pædagogiske kvalifikationer (b) en udfordring. Men efterhånden som vi i interviewene snakker rundt om bedømmelsen, bliver det tydeligt, at der lægges vægt på andet og mere end undervisningserfaringen (a). Det kan handle om, at man kigger efter initiativ, interesse, visioner og ledelseserfaring i forhold til undervisningen. Der er meget stor grad af enighed omkring dette blandt bedømmerne - forbløffende stor, set i lyset af at det langt fra er alle bedømmere, der er bekendt med universitetets retningslinjer for udarbejdelse af en portfolio og bedømmelseskriterierne. Der er en bred anerkendelse af, at den faktuelle beskrivelse af undervisningserfaring ikke kan stå alene, men må suppleres af noget mere substantielt:

"Det vi konstaterer her i den nyligst overståede runde var, at der var en enkelt eller to som reelt ikke sendte noget dokumentation med, altså, der stod måske, jamen, jeg har undervist sådan og sådan og sådan, men der var ikke noget... der var ikke nogen semesterplan eller noget, hvor man kunne sige 'ahr, den er lige tynd nok, altså'..."(SA3)

Der kigges i undervisningsportfolioen efter, hvad man har beskrevet og man har lavet, men også efter, hvad man ikke har beskrevet: 
"Hvis der for eksempel står [..] på cv'et, at vedkommende har undervist i det og det, men der er ingen papirer om de kurser, så spørger man sig selv: 'Nå, jamen, hvorfor må vi ikke høre om det?' Og omvendt altså, hvis den pågældende har vedlagt semesterplan og evalueringer, anbefalinger, prisdiplomer og forst og altså fremmest evalueringssammenfatninger eller har citeret evalueringssammenfatninger, nå ja, jamen, så har vedkommende brugt chancen, og så lagger det jo op til, at bedømmelsesudvalgets udtalelse kommer til at inkludere noget tekst som afspejler, at man har læst det materiale." (SP2)

Disse tegn kan have flere former, men især betones betydningen af refleksioner over undervisningen, $\mathrm{fx}$ i form af evalueringssammenfatninger, en 'teaching plan' eller lignende. Det vigtige her er, at man kan se personen reflektere over egen praksis, og at man kan få fat i underviseren, der ligger 'neden under cv'et'. Kvaliteten af disse refleksioner er et springende punkt, og det er ikke altid, at refleksionerne opfattes som særligt troværdige af bedømmerne:

"Altså, man kan jo sætte sig ned og så finde de fem-10 mest fremtrædende pædagogiske skribenter inden for et givent område og så lave sådan et namedropping, for at vise at man er orienteret i det, men det kan også være bare det at prøve at sætte ord på, hvad det er, en underviser vil med sin undervisning. Hvordan opfatter man forskningsbaseret undervisning, hvad er... ansvar for egen læring, altså alle de der ting [..] jeg synes, man fär en fornemmelse af, hvor [..] vant [..] de er til at reflektere over sådan noget, og hvis man holder det op mod de konkrete skemaer [semesterplaner mv.], jamen, så giver det lidt en fornemmelse af [..], hvordan det bliver omsat."(SA3)

Det er ikke alle bedømmerne, der giver udtryk for, at refleksionerne over undervisningspraksis i undervisningsportfolioen vægtlægges højt, men der er enighed om behovet for at komme 'bag om' det faktuelle og at forstå, hvordan de tænker på undervisning, og hvad der driver dem i deres undervisning.

Ikke overraskende er der en tendens til, at de bedømmere, der kommer fra fagområder, hvor hermeneutiske metoder har en fremtrædende plads, tillægger de skriftlige refleksioner over undervisningspraksis større betydning. I disse fag er der formodentlig større vanthed med denne type tekster, men der er nu også undtagelser fra dette mønster. Ud fra interviewene er der næppe tvivl om, at de bedømmere, der lægger størst vægt på ansøgerens refleksioner over egen undervisningspraksis, selv kommer fra undervisningsmiljøer, hvor undervisningen generelt prioriteres højt i forhold til forskningen - og også miljøer, hvor undervisningen (økonomisk set) udgør en væsentlig del af miljøets eksistensberettigelse. Det er tænkeligt, at refleksionerne over egen undervisning også fylder mere i ansøgernes portfolioer i disse fag. 
Når refleksionerne ikke er at finde i portfolioen, eller hvis de opfattes som utroværdige, må man gå på udkig efter andet, der kan give en indikation af ansøgers tilgang til og forståelse af undervisningen. Man skal kunne få en ide om folks ambitioner, intentioner og lyst til at undervise. Noget af det, man kan kigge efter, er, hvad man har lavet undervisningsmæssigt ud over 'det man kunne forvente'. Har man fx som postdoc været med i kursusudvikling, taget adjunktpædagogikum eller andet? Ansættelsessamtalerne kan ideelt set også bruges som mulighed for at afdække dette:

"[..] Det gør jo ikke så meget, hvor meget de rent faktisk har undervist, når de kommer og skal ansættes i så 'ung' en stilling som adjunkt eller lektor. Det er, om de har interessen til det og til at ville drive det, ikke? [...] Det, vi har brug for, det er sådan nogen som os: Tovholdere, som også godt gider trække lidt, ikke? [..] Det er jo det, man i virkeligheden skal prøve at læse: Folk som har valgt at tage pædagogikum eller har valgt at prøve sig selv af [..], de har jo vist en interesse. Så for mig er den del af det faktisk vigtigere, end om de har gjort det i tre år eller i syv år, om de har haft fem hold eller ti hold per semester [..] Der kan man jo godt lodde en interesse. For spørger man dem, er du interesseret i at undervise...? Vi havde for eksempel en, der så skrev han at han var 'so excited to see all this undervisning' og det ville han så gerne, og det var [..] excited var ud over det hele. Og så havde vi et skypeinterview med ham - så sad han og sagde undervisning, 'helst så lidt som muligt, ikke... for mig'." (HP1)

Interviewene peger på, at universitetspædagogikum sammen med kravet om medsendelse af en portfolio gør en forskel for bedømmernes mulighed for at vurdere undervisningskompetence. Ansøgerne beskriver i højere grad deres undervisning og gør det mere udførligt end tidligere, særligt de danske ansøgere. Flere angiver, at de udenlandske ansøgninger ikke er så gode som de interne og danske i forhold til beskrivelsen af undervisningskvalifikationer:

"Der laver de [udenlandske ansøgere] sådan et halvforkølet, du ved, og der står sådan lidt, hvad det er, det kan indeholde og sådan, og så prøver de det. Og der er også tit, at der er nogle, der har skrevet til mig, hvad er det, det betyder? Så prøver jeg sådan at forklare lidt. Det er lidt nemmere for de danske [..] lektorkandidater, for de har været igennem et adjunktpædagogikum. De ved godt, hvad det er, ikke?" (HA1)

Flere af bedømmerne peger endvidere på andre kilder til viden om ansøgernes undervisningskvalifikationer end det, der kan læses ud af portfolioen - en del ansøgere er jo interne og dermed velkendte for bedømmerne. Bedømmerne ved således i nogle tilfælde allerede noget om, hvordan ansøger fungerer som underviser. Dette indgår ikke i det formelle vurderingsgrundlag, men spiller alligevel ind i deres vurdering - om ikke i bedømmelsesudvalget så i det efterfølgende ansættelsesudvalg. 


\section{Ledelsens rolle i bedømmelse og ansættelse}

Respondenterne havde den opfattelse, at der er en positiv udvikling i gang i forhold til vægtlægningen af og muligheden for bedømmelse af undervisningskompetence gennem en undervisningsportfolio - og ledelsen har været med til at præge denne udvikling. En del bedømmere oplever også at den nære ledelse har mere fokus på undervisning:

"De fleste postdocs, som jeg i hvert fald har noget med at gøre lige nu, de kommer og spørger, om ikke de må få lov til at få et pædagogikum, fordi de godt kan se, at der er nogle fordele ved det... Det prøver vi selvfølgelig at være åbne overfor og få det til at passe ind. Det er klart, at det tager tid, men vi fär jo også et vist gavn af de,t fordi vi også kan bruge det aktivt, dels til at udvikle vores undervisning eller også få nogle, der rent faktisk har en kvalifikation, ikke? Så jeg ser klart en interesse og en bevidsthed omkring at undervisningen betyder meget, [..] og det er tydeligt, at vores ledelse et eller andet sted er opmærksomme. Hvis de ser nogle, der ofte er aktive undervisere, så kan de også godt se, at der er nogle, der måske har en fremtid på stedet." (HA2)

Samtidig med at ledelsen sender signaler om at undervisning skal prioriteres, og man har vedtaget, at der skal medsendes en undervisningsportfolio ved lektor- og professoransøgninger, så oplever nogle, at når det kommer til stykket i ansættelsessituationen, så prioriterer ledelsen anderledes:

"Og man kan sige, nogle bedømmelser er måske grundigt lavet, altså fra bedømmelsesudvalget, jeg tror da, folk gør det, så godt de synes, det kan gøres. Min erfaring er bare, at det ikke betyder en skid, når du skal ansætte folk. Det er ikke det, der tæller. Det er det, der er specielt, ikke? Det [..] du falder på, det er din forskning. Det er det, du bliver vurderet på! Det her undervisning, det er bare noget, du bliver sat til. At på papiret, ja ja, det er simpelthen så vigtigt, det her, men i realiteten er det fuldstændig ligegyldigt, ikke?" (HA1)

Det kommer især til udtryk i forhold til den videre proces i ansættelsesudvalget og ved ansættelsessamtalerne. Ved nogle af ansættelsessamtalerne bliver der slet ikke snakket undervisning:

"Undervisning taler vi ikke om. Det er der faktisk ikke blevet. Jeg kan huske, da jeg selv blev [ansat], der havde jeg store ideer om undervisning, og der sagde [dekanen] 'ja, det, ved du hvad, det kan du altid lige tage senere', altså. Så det er ikke vægtet, det må man bare sige, det er det ikke. [..]Jeg tror aldrig, jeg har hørt nogen endnu stille spørgsmål [om undervisning]. Det er der heller ikke lagt op til. Det er sgu da interessant." (HA1) 
Dette billede er (heldigvis) ikke generelt og handler mere om, hvordan processen i ansættelsesudvalget forløber, end hvad der foregår i bedømmelsesudvalget. Flere andre respondenter giver udtryk for, at undervisningen gives prioritet også i ansættelsessamtalen:

"Altså, der er jo virkelig ingen, der har lyst til at fastansætte folk, der ikke kan undervise, altså, det er bare en dræber, ikke? Det har vi jo ikke råd til, at have sådan en, der ikke kan undervise. Så kan de altså have rigtig gode publikationer, og så tager vi dem ikke alligevel." (HP2)

\section{Diskussion og konklusion}

Denne interviewundersøgelse bekræfter antagelsen om, at forskning generelt vægtes højere end undervisning i både undervisningsmiljøerne og bedømmelsen af ansøgernes kvalifikationer, men at undervisningskvalifikationer gives en væsentlig vægt i bedømmelserne og - som regel - også i den efterfølgende ansættelsesproces. Undervisningens status og betydning varierer i forhold til det konkrete opslag og den påtænkte jobfunktion, men også fagområderne imellem.

Et centralt spørgsmål i undersøgelsen var, hvilken rolle de centralt vedtagne vurderingskriterier spiller for bedømmelsesarbejdet, og det var en antagelse, at vurderingskriterierne fungerede som grænseobjekt mellem ansøger, bedømmelsesudvalgets arbejde og ledelsen. Imidlertid er det klart fra interviewene, at ganske få (om nogle) af bedømmerne var bekendt med de centralt fastsatte vurderingskriterier, og flere bedømmere angav, at de aldrig havde set kriterierne. Der er således ikke tale om en kriteriebaseret bedømmelse, men at bedømmerne udfører deres bedømmelse på baggrund af ikke klart ekspliciterede normer for undervisningskompetence. Ikke desto mindre er der ret god overensstemmelse mellem institutionens formelle kriterier og de lokale, tavse normer, der findes i TLR, og som lægges til grund for bedømmelsen. Det gælder særligt vurderingen af ansøgernes undervisningserfaring - kriteriernes punkt (a). Der er også blandt bedømmerne en enighed om, at der er behov for en vurdering, som rækker ud over dette, og som siger noget om ansøgerens intentioner og tænkning om undervisningen - kriteriernes punkt (b). På baggrund af det begrænsede datasæt, som en kvalitativ undersøgelse som denne bygger på, ser vi en tendens til at de mere hermeneutiske fagområder har lettere ved at vurdere undervisningskompetencer, kriteriernes punkt (b).

Det er endvidere klart, at de tavse normer, der lægges til grund for vurderingen, er i udvikling, og at de har større vægt i forhold til forskningen end tidligere. Flere peger på at universitetspædagogikum og de unge undervisere, der har haft universitetspædagogikum, er med til at præge denne udvikling - både gennem deres påvirkning af den lokale undervisningskultur og fordi de ved, hvordan man kan lave en god undervisningsportfolio. De sætter så at sige en standard for, hvad en god portfolio kan indeholde. Nogle bedømmere peger også på, at den lokale ledelse understøtter denne 
udvikling. Det er derfor tænkeligt, at vurderingskriterierne dermed alligevel tjener deres tiltænkte funktion, selv om bedømmerne ikke kender den præcise ordlyd af dem - ansøgerne har forholdt sig til dem, og ledelsen er (måske!) også bekendt med dem.

Nogle af bedømmerne giver udtryk for en tvivl om, hvorvidt eller hvordan portfolioen kan bruges til at vurdere undervisningskompetence, og enkelte har en oplevelse af, at ansættelsesudvalget ikke vil bruge en sådan bedømmelse konstruktivt. Her indgår først og fremmest undervisningserfaringen i bedømmelsen. I flere af disse tilfælde foregår bedømmelsen af undervisningskompetencen så i forbindelse med ansættel-sessamtalen. Enkelte oplever dog, at der ikke er tid eller rum til samt interesse fra ledelsen $\mathrm{i}$ at inddrage bedømmelse af undervisningskompetence i ansættelsessamta-len, som alene kommer til at omhandle udviklingen af forskningen og - måske især - ansøgers mulighed og potentiale for at tiltrække eksterne midler. I disse tilfælde bliver undervisningskompetencen således slet ikke afdækket i ansættelsesforløbet. Dette opleves som særdeles frustrerende for de involverede bedømmere, da det giver ind-tryk af, at ledelsen ikke er oprigtig i dens fokus på undervisningens kvalitet.

Hvad skulle der til, for at bedømmelsesudvalgene kunne give en kriteriebaseret og mere ensartet bedømmelse? Først og fremmest kunne institutionen tage ansvar for at gøre institutionens bedømmere og medlemmer af ansættelsesudvalget bekendt med kriterierne. Derudover kunne man udbyde kurser i bedømmelse af undervis-ningsportfolioer og sikre, at mindst et medlem af bedømmelses- og ansættelsesud-valg havde deltaget i kurset.

Sofie Kobayashi er adjunkt i naturvidenskabsdidaktik. Hendes undervisning og forskning ligger inden for det universitetspædagogiske felt med fokus på ph.d.-uddannelse og vejledning samt kompetenceudvikling indenfor vejledning og undervisning.

Nana Quistgaard er tidligere postdoc i museumsdidaktik og senere konsulent i naturvidenskabsdidaktik. Hun har undersøgt affektive påvirkninger og dialogiske processer i forbindelse med skolebesøg på naturvidenskabelige museer. Endvidere har hun arbejdet med brugen af undervisningsportfolioer samt undervist i universitetspædagogik og naturvidenskabelig kommunikation.

Camilla Østerberg Rump er lektor i naturvidenskabsdidaktik mhp. undervisning på universitets-niveau. Hendes undervisning og forskning omhandler udvikling af undervisningskompetence og studerendes læring i de naturfaglige uddannelser. Nyeste projekter handler om studielederes tilgang til ledelse, udvikling af undervisningskompetence gennem universitetspædagogikum, studerendes opfattelse af forskningsbaseret undervisning samt bedømmelse af underviserkompetence.

Frederik Voetmann Christiansen er lektor i naturvidenskabsdidaktik. Hans forskning og undervisning er primært inden for universitetspædagogik og uddannelsesforskning, natur- og sundhedsvidenskabelig didaktik, samt natur- og sundhedsvidenskabelig videnskabsteori. 


\section{Litteratur}

Akkerman, S. F., \& Bakker, A. (2011). Boundary crossing and boundary objects. Review of educational research, 81(2), 132-169.

Becher, T. (1994). The significance of disciplinary differences. Studies in Higher Education, 19(2), 151-161.

Christiansen, F. V., Damlund, V., \& Jacobsen, J. C. (2014). Undervisningsportfolio erfaringer og veje frem. Delrapport 1-1 i KUUPI udviklingsprojekt om undervisningsportfolio IND's skriftserie (Vol. 31). København: Institut for Naturfagenes Didaktik, Københavns Universitet.

De Rijdt, C., Tiquet, E., Dochy, F., \& Devolder, M. (2006). Teaching portfolios in higher education and their effects: An explorative study. Teaching and Teacher Education, 22(8), 1084-1093.

Kvale, S., \& Brinkmann, S. (2009). InterViews: Learning the craft of qualitative research interviewing: Sage Publications.

Roxå, T., \& Mårtensson, K. (2009). Significant conversations and significant networksexploring the backstage of the teaching arena. Studies in Higher Education, 34(5), 547-559.

Ryegård, Å., Apelgren, K., \& Olsson, T. (2010). Att belägga, bedöma och belöna pedagogisk skicklighet. Myndigheten för nätverk och samarbete inom högre utbildning.

Seldin, P., \& Miller, J. E. (2009). The academic portfolio: a practical guide to documenting teaching, research, and service (Vol. 132): John Wiley \& Sons.

Smith, K., \& Tillema, H. (2003). Clarifying different types of portfolio use. Assessment \& Evaluation in Higher Education, 28(6), 625-648.

Star, S. L., \& Griesemer, J. R. (1989). Institutional ecology, 'translations' and boundary objects: Amateurs and professionals in Berkeley's Museum of Vertebrate Zoology, 1907-39. Social Studies of Science, 19(3), 387-420.

Tigelaar, D. E. H., Dolmans, D. H. J. M., Wolfhagen, I. H. A. P., \& van der Vleuten, C. P. M. (2005). Quality issues in judging portfolios: implications for organizing teaching portfolio assessment procedures. Studies in Higher Education, 30(5), 595-610.

Trowler, P., \& Cooper, A. (2002). Teaching and Learning Regimes: Implicit theories and recurrent practices in the enhancement of teaching and learning through educational development programmes. Higher Education Research \& Development, 21(3), 221-240. 